\title{
Role of transforming growth factor- $\beta 1$ in gene expression and activity of estradiol and progesterone-generating enzymes in FSH-stimulated bovine granulosa cells
}

\author{
Xiaofeng Zheng, Christopher A Price, Yves Tremblay, Jacques G Lussier and Paul D Carrière \\ Faculté de Médecine Vétérinaire, Centre de Recherche en Reproduction Animale (CRRA), Université de Montréal, \\ St-Hyacinthe, Québec, Canada J2S 7C6 and ${ }^{1}$ Laboratory of Ontogeny and Reproduction, Pavillon CHUL, Ob/Gyn \\ Department, Faculty of Medicine, Centre Hospitalier Universitaire de Québec (CHUQ), Centre de Recherche en \\ Biologie de la Reproduction (CRBR), Laval University, Québec City, Québec, Canada G1V 4G2
}

Correspondence should be addressed to P D Carrière; Email: paul.d.carriere@umontreal.ca

\begin{abstract}
Survival and inhibitory factors regulate steroidogenesis and determine the fate of developing follicles. The objective of this study was to determine the role of transforming growth factor- $\beta 1$ (TGFB1) in the regulation of estradiol-17 $\beta\left(E_{2}\right)$ and progesterone ( $\left.P_{4}\right)$ secretion in FSHstimulated bovine granulosa cells. Granulosa cells were obtained from 2 to $5 \mathrm{~mm}$ follicles and cultured in serum-free medium. FSH dose (1 and $10 \mathrm{ng} / \mathrm{ml}$ for 6 days) and time in culture $(2,4$, and 6 days with $1 \mathrm{ng} / \mathrm{ml} \mathrm{FSH})$ increased $E_{2}$ secretion and mRNA expression of $E_{2}$-related enzymes cytochrome $\mathrm{P450}$ aromatase (CYP19A1) and 17 $\beta$-hydroxysteroid dehydrogenase type 1 (HSD17B1), but not HSD17B7. TGFB1 in the presence of FSH (1 ng/ml) inhibited $E_{2}$ secretion, and decreased mRNA expression of FSH receptor (FSHR), CYP19A1, and HSD17B1, but not $H S D 17 B 7$. FSH dose did not affect $\mathrm{P}_{4}$ secretion and mRNA expression of $3 \beta$-hydroxysteroid dehydrogenase $(H S D 3 B)$ and $\alpha$-glutathione $S$-transferase (GSTA), but inhibited the amount of steroidogenic acute regulatory protein (STAR) mRNA. Conversely, $\mathrm{P}_{4}$ and mRNA expression of STAR, cytochrome $\mathrm{P} 450$ side-chain cleavage (CYP11A1), HSD3B, and GSTA increased with time in culture. TGFB1 inhibited $\mathrm{P}_{4}$ secretion and decreased mRNA expression of STAR, CYP11A1, HSD3B, and GSTA. TGFB1 modified the formation of granulosa cell clumps and reduced total cell protein. Finally, TGFB1 decreased conversion of androgens to $E_{2}$, but did not decrease the conversion of estrone $\left(E_{1}\right)$ to $E_{2}$ and pregnenolone to $P_{4}$. Overall, these results indicate that TGFB1 counteracts stimulation of $E_{2}$ and $P_{4}$ synthesis in granulosa cells by inhibiting key enzymes involved in the conversion of androgens to $E_{2}$ and cholesterol to $P_{4}$ without shutting down HSD17B reducing activity and HSD3B activity. Reproduction (2008) $136447-457$
\end{abstract}

\section{Introduction}

In cattle, follicle development occurs in waves consisting of rhythmic emergence and growth of a new cohort of antral follicles (Ireland et al. 2000). During this process, the proportion of follicles undergoing atresia increases dramatically with follicular diameter and the rate of atresia doubles between 2 and $8 \mathrm{~mm}$ (Lussier et al. 1987). At the final growth phase, most follicles are atretic and only one follicle (exceptionally two) is selected to become dominant and continue to grow until ovulation (Fortune et al. 2001). Many factors are involved in follicular development, including gonadotropins, steroid hormones, cytokines, and other endocrine, paracrine, and autocrine factors. These factors induce cell death or survival and thus determine the fate of the growing follicle.

Gonadotropin stimulation of responsive follicles is associated with increased synthesis of estradiol-17 $\left(E_{2}\right)$ and progesterone $\left(\mathrm{P}_{4}\right)$, the two key steroid hormones associated with the development of the ovulatory follicle (Price et al. 1999, Kolibianakis et al. 2005). $E_{2}$ is produced by granulosa cells and is important for granulosa cell growth, attenuation of granulosa cell apoptosis, and positive and negative feedback regulation of the hypothalamic-pituitary-ovarian axis (Kolibianakis et al. 2005). In ruminants and humans, gonadotropin stimulation of $E_{2}$ requires luteinizing hormone $(\mathrm{LH})$ stimulation of theca cells to produce androgens, mostly as androstenedione $\left(\mathrm{A}_{4}\right)$, and follicle-stimulating hormone (FSH)-mediated conversion of theca-derived $A_{4}$ to $E_{2}$ in granulosa cells (Fortune 1986, Hillier et al. 1994). $A_{4}$ is converted to estrone $\left(E_{1}\right)$ by cytochrome P450 aromatase (CYP19A1) and then into $E_{2}$ by $17 \beta$-hydroxysteroid dehydrogenase (HSD17B) reducing enzymes (Hillier etal. 1994, Mindnich et al. 2004). Granulosa cells also produce $P_{4}$, which is necessary for the induction of ovulation (Drummond 2006). The production of $P_{4}$ involves transformation of cholesterol to pregnenolone $\left(\mathrm{P}_{5}\right)$ by the cytochrome $\mathrm{P} 450$ side-chain cleavage (CYP11A1) followed by the conversion of $\mathrm{P}_{5}$ to $\mathrm{P}_{4}$ by $3 \beta$-hydroxysteroid dehydrogenase (HSD3B). In addition, $\alpha$-glutathione $S$-transferase (GSTA) is 
expressed in bovine granulosa cells and codes for a protein with high HSD3B activity (Rabahi et al. 1999, Raffalli-Mathieu et al. 2007). In vivo, most of the steroidogenic enzyme genes are not expressed in granulosa cells of small bovine antral follicles $(0.4-4 \mathrm{~mm}$; Bao \& Garverick 1998). In granulosa cells, expression of CYP19A1 and CYP11A1 gradually increases during follicle growth, and HSD3B is first observed in non-atretic follicles at $\sim 8 \mathrm{~mm}$ (Xu et al. 1995, Bao et al. 1997). These data indicate that the timely expression of steroidogenic enzymes at distinct periods of follicular development is important for the selection of the dominant follicle and successful ovulation. A better characterization of the regulation of $E_{2}$ and $P_{4}$ synthesis in granulosa cells will improve our understanding of follicle development.

In recent years, much attention has focused on the role of the members of the transforming growth factor- $\beta$ (TGFB) superfamily acting as paracrine and autocrine factors to modulate ovarian function and fertility (Knight \& Glister 2006). TGFB1, which is the most extensively studied factor of this family, is present in granulosa and theca cells and in the vascular system of the ovary in many species (Nilsson et al. 2003, Juengel \& McNatty 2005), and has been shown to either stimulate or inhibit $\mathrm{E}_{2}$ and $\mathrm{P}_{4}$ synthesis. For instance, TGFB1 stimulated $E_{2}$ and $P_{4}$ secretion from rodent granulosa cells (Zachow et al. 1999, Knight \& Glister 2006), whereas TGFB1 inhibited granulosa cell secretion of $\mathrm{E}_{2}$ and $\mathrm{P}_{4}$ from pigs and ruminants (Chang etal. 1996, Wandji \& Fortune 1996, Ford \& Howard 1997, Juengel et al. 2004, Ouellette et al. 2005). These reports detailing the effect of TGFB1 on ovarian cells appear to be highly dependent on the species studied, stage of follicle differentiation, and the presence of different growth factors as co-treatments, and the mechanism of TGFB1 action in granulosa cells is not clear. In vivo, the complexities of hormonal interactions with the cytokines produced by ovarian cells limit our investigations of steroidogenesis in follicle development. Fortunately, $\mathrm{E}_{2}$ secretion can be maintained for several days in bovine granulosa cells cultured in vitro with $\mathrm{FSH}$ in serum-free conditions (Gutierrez et al. 1997). This in vitro model mimics the gradual increase in $E_{2}$ secretion seen in the growing follicles and can be used to identify the key factors regulating steroidogenesis in granulosa cells. Therefore, the objective of the present study was to determine the effect of TGFB1 on $\mathrm{E}_{2}$ and $\mathrm{P}_{4}$ synthesis and the corresponding expression and activity of key steroidogenic enzymes in FSH-stimulated bovine granulosa cells.

\section{Results}

\section{Effect of FSH dose and time in culture}

In granulosa cells cultured for 6 days, FSH at 1 and $10 \mathrm{ng} / \mathrm{ml}$ had no effect on $\mathrm{P}_{4}$ synthesis, but significantly increased $\mathrm{E}_{2}$ secretion (Fig. $1 \mathrm{~A}$ and $\mathrm{F}$ ). FSH decreased steroidogenic acute regulatory protein (STAR) mRNA level, increased CYP11A1 (only at the $10 \mathrm{ng} / \mathrm{ml}$ dose), and did not affect HSD3B and GSTA mRNA levels (Fig. 1B-E). For $\mathrm{E}_{2}$ secretion, $\mathrm{FSH}$ had no effect on HSD17B7 mRNA level but increased CYP19A1 and HSD17B1 mRNA levels (Fig. $1 \mathrm{H}-\mathrm{J}$ ). In the presence of $\mathrm{FSH}$ at $1 \mathrm{ng} / \mathrm{ml}$, both $\mathrm{P}_{4}$ and $\mathrm{E}_{2}$ accumulation increased from days 2 to 6 (Fig. $2 \mathrm{~A}$ and $\mathrm{F}$ ). In agreement with increased secretion of $\mathrm{P}_{4}$ with time in culture, mRNA expression of the $\mathrm{P}_{4}$-related enzymes STAR, CYP11A1, $H S D 3 B$, and GSTA also increased with time (Fig. 2B-E). For $\mathrm{E}_{2}$-related enzymes, time in culture had no effect on HSD17B7 mRNA level but CYP19A1 and HSD17B1 mRNA levels increased with time (Fig. $2 \mathrm{H}-\mathrm{J}$ ).

\section{Effects of TGFB1 on secretion of steroid hormones and $m R N A$ expression and activity of steroidogenic enzymes}

Since $\mathrm{P}_{4}$ and $\mathrm{E}_{2}$ secretion was stimulated in granulosa cells cultured for 6 days with $1 \mathrm{ng} / \mathrm{ml} \mathrm{FSH}$ (see above), we examined the effect of TGFB1 on steroid hormones and mRNA expression of steroidogenic enzymes under this condition. Addition of TGFB1 caused a significant dosedependent inhibition of $\mathrm{P}_{4}$ and $\mathrm{E}_{2}$ secretion (Fig. 3). To determine enzymatic activities, the tritiated steroid hormone precursors of $A_{4}$, testosterone $(T), E_{1}$, and $P_{5}$ were converted to the corresponding radiolabeled product $\left(E_{2}\right.$ and $\left.P_{4}\right)$ confirming that the CYP19A1, reducing $\mathrm{HSD} 17 \mathrm{~B}$, and $\mathrm{HSD} 3 \mathrm{~B}$ activities measured were specific. When granulosa cells were cultured with $0.5 \mathrm{ng} / \mathrm{ml} \mathrm{TGFB} 1$, there was a significant inhibition of combined CYP19A1 and HSD17B activity as measured by the conversion of $\left[{ }^{3} \mathrm{H}\right] \mathrm{A}_{4}$ to $\left[{ }^{3} \mathrm{H}\right] \mathrm{E}_{2}$ (Fig. $4 \mathrm{~A}$ ), although the intermediary product $\left[{ }^{3} \mathrm{H}\right] \mathrm{E}_{1}$ was not detected. Both doses of TGFB1 caused a significant inhibition in the CYP19A1 activity measured by the conversion of $\left[{ }^{3} \mathrm{H}\right] \mathrm{T}$ to $\left[{ }^{3} \mathrm{H}\right] \mathrm{E}_{2}$ (Fig. 4B). TGFB1 did not alter HSD17B reducing activity or HSD3B activity (Fig. 5). Corresponding to the decreased secretion of $\mathrm{P}_{4}$ and $\mathrm{E}_{2}$, TGFB1 caused a significant inhibition in the mRNA expression of STAR, CYP11A1, HSD3B, GSTA, CYP19A1, HSD17B1, and FSHR (Fig. 6). However, HSD17B7 mRNA was not changed by the treatment of TGFB1 (Fig. 6I).

\section{Cell morphology and total cell protein}

Granulosa cells were seeded onto wells and cultured for 6 days in serum-free medium. The granulosa cells initially formed tightly packed aggregates from day 2, which enlarged with time in culture (data not shown). When TGFB1 was added to FSH-stimulated cells, granulosa cell clumps were smaller and appeared more spherical than control cells (Fig. 7D). Total cell protein was 30 and 38\% higher in the 1 and $10 \mathrm{ng} / \mathrm{ml} \mathrm{FSH}$-treated groups compared with the control group without FSH (Fig. 7A). By contrast, in the presence of $1 \mathrm{ng} / \mathrm{ml} \mathrm{FSH}$, the highest dose of TGFB1 $(0.5 \mathrm{ng} / \mathrm{ml})$ decreased total cell protein by $23 \%$ compared 

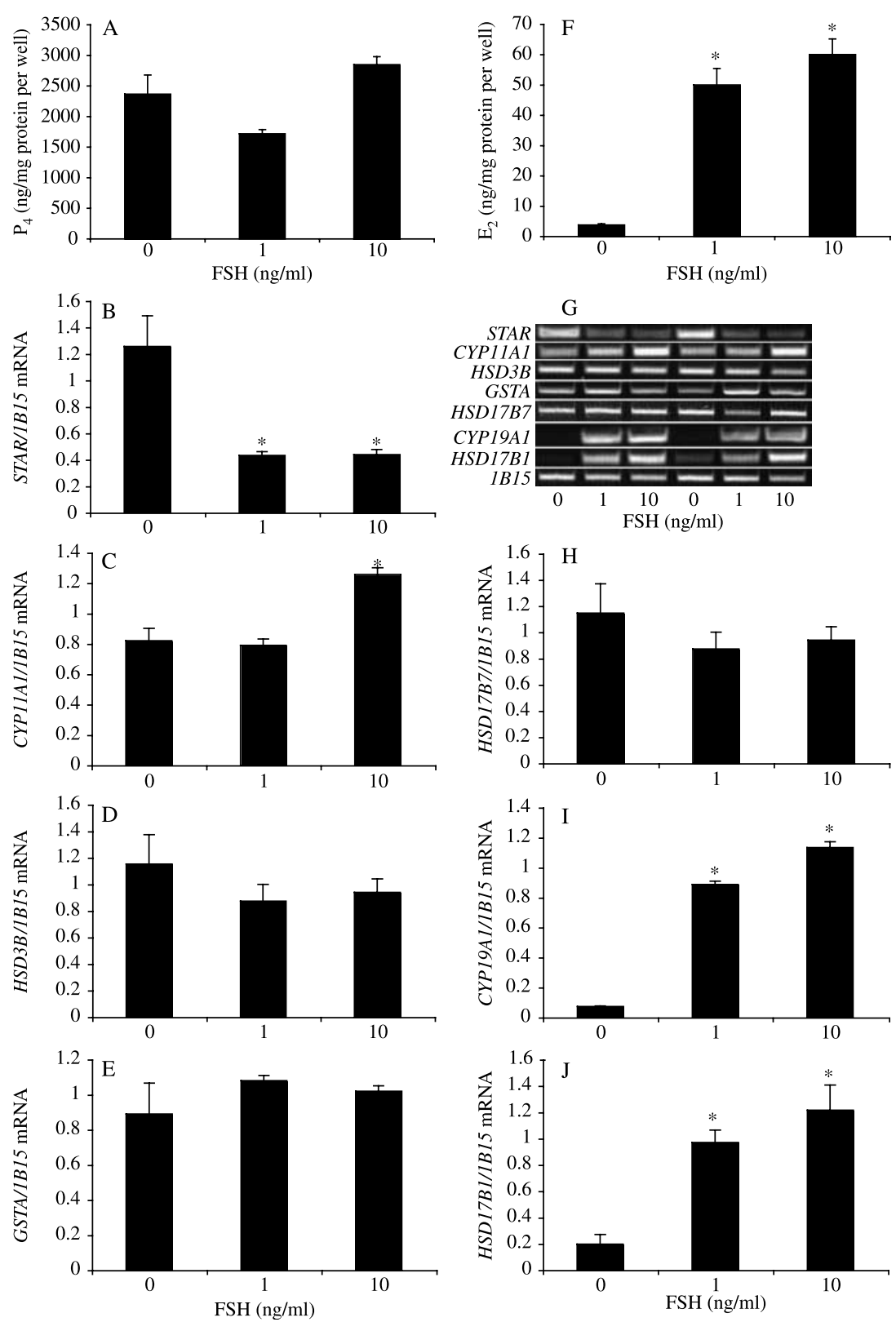

Figure 1 Effect of FSH dose $(0,1$, and $10 \mathrm{ng} / \mathrm{ml})$ on secretion of estradiol $\left(\mathrm{E}_{2}\right)$ and progesterone $\left(\mathrm{P}_{4}\right)$ and mRNA expression of steroidogenic enzymes in bovine granulosa cells. The cells were cultured for 6 days without serum in the presence of 0,1 , and $10 \mathrm{ng} / \mathrm{ml} \mathrm{FSH}$ starting at day 0 . The culture medium and cellular RNA were collected on day 6 .

( $A$ and $F$ ) The data represent secretion of $E_{2}$ and $P_{4}$ during the last $48 \mathrm{~h}$ of culture. Levels of STAR, CYP11A1, HSD3B, GSTA, HSD17B7, CYP19A1, and $H S D 17 B 1$ mRNA expression were measured by semi-quantitative RT-PCR. (B-E and H-J) Data are presented as the amount of steroidogenic enzyme expressed relative to the amount of expression of the constitutively expressed gene 1B15. Data are means \pm s.E.M. of three separate culture replicates. Asterisk indicates that the mean is significantly different from the 0 dose control ( $P<0.05$, one-way ANOVA, with Dunnett's test). (G) Representative agarose gel from two replicates showing PCR products for each steroidogenic enzyme and constitutively expressed housekeeping gene $1 B 15$. with the control group without TGFB1 (Fig. 7B). Furthermore, in the absence of FSH, 6 days of treatment with 0.1 , 0.5 , or $1 \mathrm{ng} / \mathrm{ml}$ TGFB1 had no significant effect on total cell protein (data not shown).

\section{Discussion}

The regulation of $\mathrm{E}_{2}$ and $\mathrm{P}_{4}$ production in granulosa cells is critical for ovarian follicle growth. The synthesis of $E_{2}$ from androgens requires aromatization by CYP19A1. In agreement with previous studies (Gutierrez et al. 1997, Silva \& Price 2000, Sahmi et al. 2004), the physiological dose of $\mathrm{FSH}$ used in the present study $(1 \mathrm{ng} / \mathrm{ml})$ stimulated $E_{2}$ secretion and abundance of CYP19A1 and $H S D 17 B 1$ mRNA. Under this stimulatory condition,
TGFB1 caused a marked inhibition of $E_{2}$ secretion and CYP19A1 activity, due to decreased expression of CYP19A1 mRNA. These findings concur with those obtained in extragonadal tissues where TGFB1 was shown to inhibit CYP19A1 activity, CYP19A1 mRNA, and CYP19A1 protein levels in cultured human fetal hepatocytes, trophoblast cells, and adipose stroma cells (Simpson et al. 1989, Rainey et al. 1992, Luo et al. 2002). The conversion of $A_{4}$ to $E_{2}$ also requires HSD17B reducing activity; however, TGFB1 did not affect HSD17B activity in the present study. TGFB1 did inhibit $H S D 17 B 1$ expression, suggesting that another enzyme may be contributing to total HSD17B activity. Another enzyme known to convert $\mathrm{E}_{1}$ to $\mathrm{E}_{2}$ is $H S D 17 B 7$ (Krazeisen et al. 1999, Krusche et al. 2001), and in the 

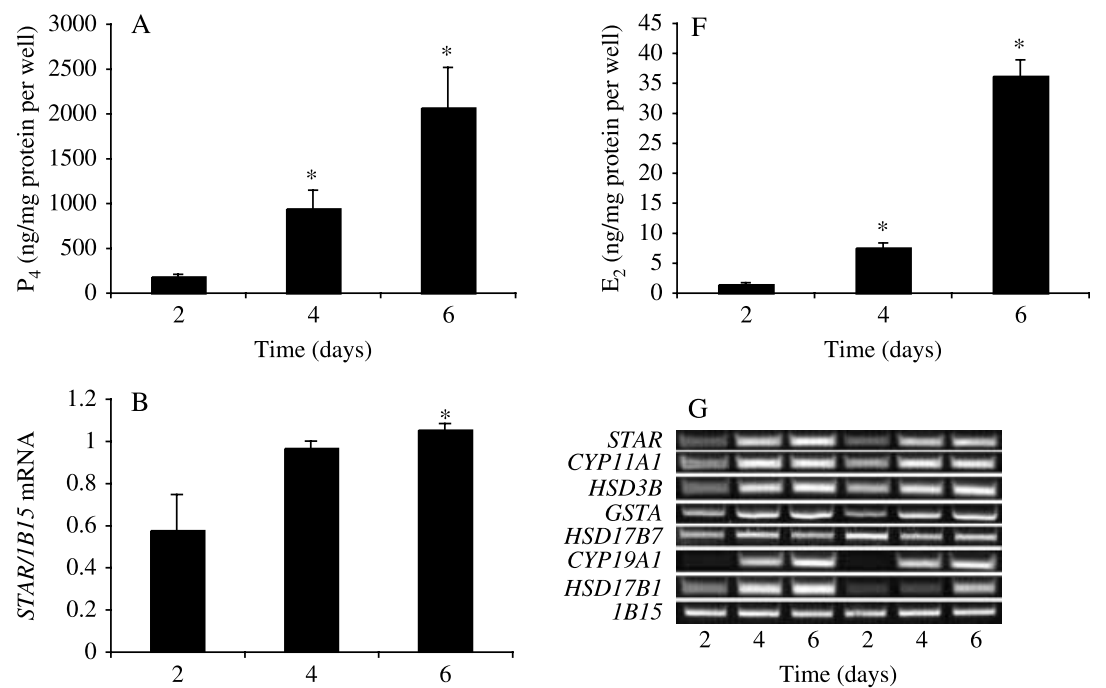

G
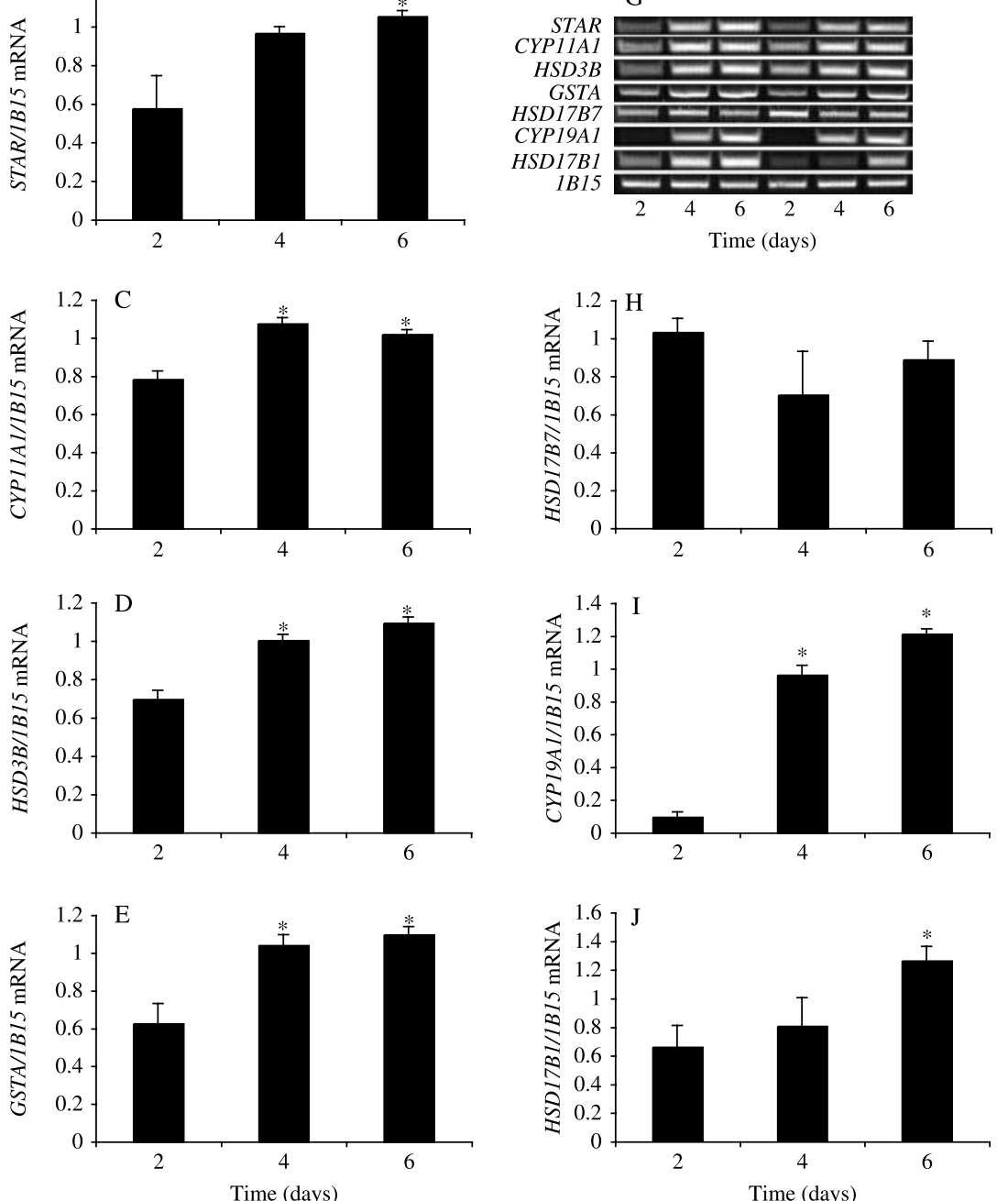

Figure 2 Effect of time in culture (2, 4, and 6 days) on secretion of $\mathrm{E}_{2}$ and $\mathrm{P}_{4}$ and $\mathrm{mRNA}$ expression of steroidogenic enzymes in bovine granulosa cells. Granulosa cells were cultured in serum-free medium with $1 \mathrm{ng} / \mathrm{ml} \mathrm{FSH}$ starting at day 0 . ( $A$ and $F$ ) The data represent secretion of $E_{2}$ and $P_{4}$ during the last $48 \mathrm{~h}$ of culture. (B-E and $\mathrm{H}-\mathrm{J}$ ) Abundance of STAR, CYP11A1, HSD3B, GSTA, HSD17B7, CYP19A1, and HSD17B1 mRNA was measured by semi-quantitative RT-PCR and normalized to the housekeeping gene 1B15. Data are means \pm s.E.M. of three separate culture replicates. Asterisk indicates that the mean is significantly different from control at day $2(P<0.05$, one-way ANOVA, with Dunnett's test). (G) Representative agarose gel from two replicates showing PCR products for each steroidogenic enzyme and constitutively expressed housekeeping gene $1 B 15$. present study this isoform was detected in bovine granulosa cells and was not inhibited by TGFB1. In rodent and rabbit ovaries, this isoform is present only in the corpus luteum and was first reported as the prolactin receptor-associated protein (Nokelainen et al. 1998, Krusche et al. 2001, Risk et al. 2005). In humans, $H S D 17 B 7$ transcript was found in the ovaries of nonpregnant, but not pregnant, women (Krazeisen et al. 1999). The mRNA expression of HSD17B7 was not affected by TGFB1 in agreement with a lack of the effect of TGFB1 on HSD17B activity. FSH dose and time in culture also did not affect the expression of HSD17B7 mRNA in the present study. For HSD17B activity, a 1000fold excess of unlabeled $E_{1}$ had to be added and incubation time had to be shortened to obtain comparable conditions of substrate excess, indicating that HSD17B reducing activity is very high in cultured bovine granulosa cells. The high HSD17B activity could explain why the CYP19A1 product $\left[{ }^{3} \mathrm{H}\right] \mathrm{E}_{1}$ was undetectable in the presence or absence of TGFB1. 

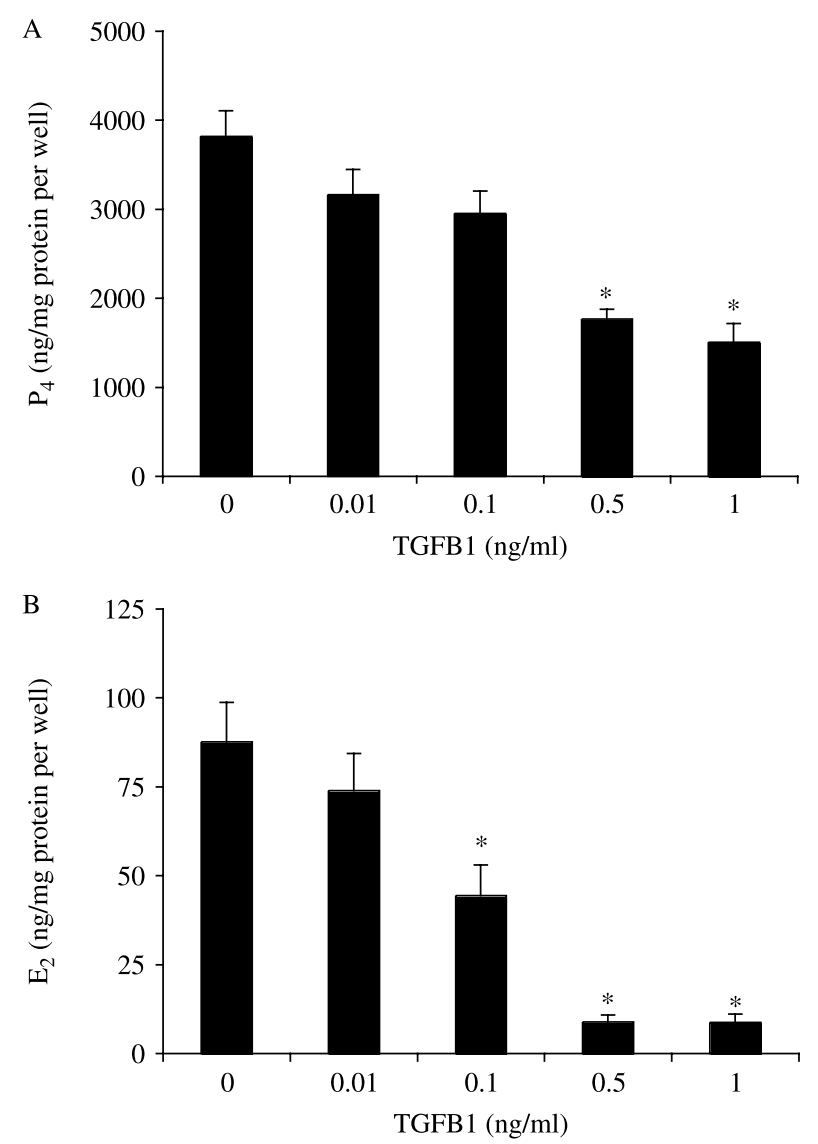

Figure 3 Effect of TGFB1 on $\mathrm{E}_{2}$ and $\mathrm{P}_{4}$ secretion from cultured bovine granulosa cells. The cells were cultured for 6 days without serum in the presence of $1 \mathrm{ng} / \mathrm{ml} \mathrm{FSH}$ and were treated with TGFB1 beginning on the first day of culture. The medium was collected on day 6 and the data represent steroid produced during the last $48 \mathrm{~h}$ of culture. Data were corrected for total cell protein and represent means \pm s.E.M. derived from four different pools of ovaries. Asterisk indicates that steroid hormone secretion was significantly different from the 0 dose control group ( $P<0.05, n=4$, one-way ANOVA, with Dunnett's test).

In developing antral follicles, a positive $\mathrm{E}_{2} / \mathrm{P}_{4}$ ratio must be maintained and it is critical to limit $\mathrm{P}_{4}$ secretion until the time of ovulation induction, because premature increase in $\mathrm{P}_{4}$ is associated with follicular atresia (Ireland \& Roche 1982, Irving-Rodgers et al. 2003). In agreement with the above, a low dose of FSH stimulated $\mathrm{E}_{2}$ but not $\mathrm{P}_{4}$ in the present study and CYP11A1 was only stimulated by the highest dose of FSH $(10 \mathrm{ng} / \mathrm{ml})$. Additionally, the present study is the first report showing that FSH down-regulates the expression of STAR in vitro. This finding may explain why STAR is undetectable in the granulosa of healthy antral follicles at any size in vivo (Soumano \& Price 1997, Bao et al. 1998). In our timecourse experiments, in the presence of low dose of $\mathrm{FSH}$, the production of $\mathrm{P}_{4}$ increased as well as the expression of STAR, CYP11A1, HSD3B, and GSTA. These findings are in agreement with a previous study (Sahmi et al. 2004), which showed an increase with time in HSD3B and CYP11A1. Overall, these results indicate that $\mathrm{P}_{4}$
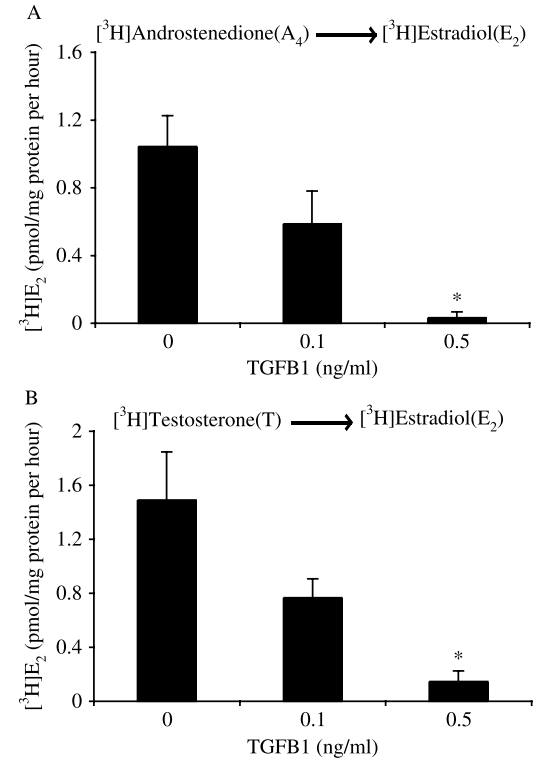

Figure 4 Effect of TGFB1 on conversion of androgens to $E_{2}$. Bovine granulosa cells were cultured for 6 days in serum-free medium. Labeled steroid precursor was added on day 6 and incubated for $3 \mathrm{~h}$ and enzymatic activity assays were conducted as described in Materials and Methods. Data are means \pm S.E.M. of three separate culture replicates. (A) Conversion of $\left[{ }^{3} \mathrm{H}\right] \mathrm{A}_{4}$ to $\left[{ }^{3} \mathrm{H}\right] \mathrm{E}_{2}(\mathrm{CYP} 19 \mathrm{~A} 1+\mathrm{HSD} 17 \mathrm{~B}$ reducing activity). (B) $\left[{ }^{3} \mathrm{H}\right] \mathrm{T}$ conversion to $\left[{ }^{3} \mathrm{H}\right] \mathrm{E}_{2}$ (CYP19A1 activity). Asterisk indicates that enzyme activity is significantly different from the 0 dose control group ( $P<0.05, n=3$, one-way ANOVA, with Dunnett's test).

increases spontaneously in cultured granulosa cells and that readily available stores of cholesterol are present in granulosa cells, which can be transformed to $\mathrm{P}_{4}$ by CYP11A1, HSD3B, and GSTA. Similar to the effect of TGFB1 on $E_{2}$ synthesis, TGFB1 also inhibited the progestin synthetic pathway. TGFB1 inhibited $\mathrm{P}_{4}$ secretion and abundance of mRNA encoding STAR, CYP11A1, HSD3B, and GSTA, which are required for sustained production of $\mathrm{P}_{4}$ from cholesterol. These data are consistent with the effects of TGFB1 on STAR, CYP11A1, and HSD3B in thecal, adrenocortical, and adrenal tumor cells among different species (Rainey et al. 1991, Cherradi et al. 1995, Naaman-Reperant et al. 1996, Attia et al. 2000, Herrmann et al. 2002), and this is the first time that TGFB1 has been shown to inhibit mRNA encoding GSTA. Surprisingly, despite the reduced abundance of HSD3B and GSTA mRNA, TGFB1 did not affect total HSD3B activity. Similarly, TGFB1 did not significantly alter HSD3B activity in the rat fetal testis (Gautier et al. 1997). TGFB1 may have stabilized the corresponding enzyme proteins of HSD $3 B$ and GSTA or, alternatively, other unknown gene products with HSD3B activity may be involved.

In agreement with previous morphological studies (Gutierrez et al. 1997, Marsters et al. 2003), FSH increased cell number. In this model, it has been suggested that after dispersion, granulosa cells revert to 

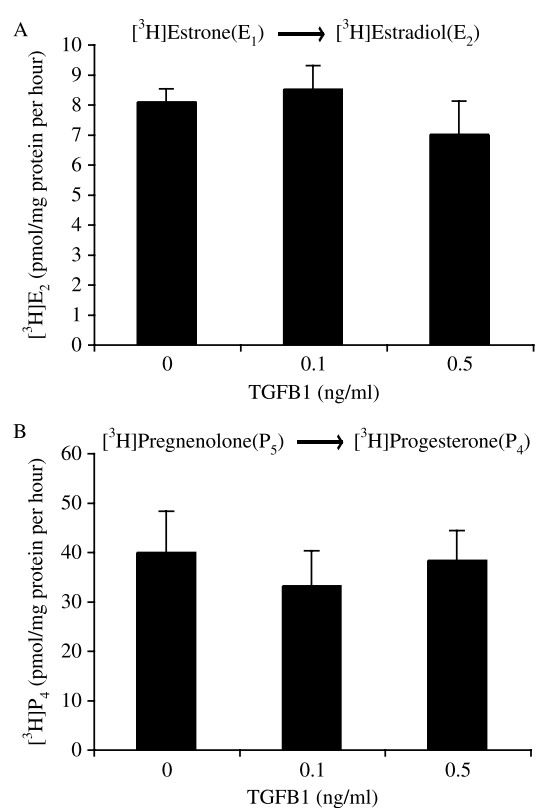

Figure 5 Effect of TGFB1 on (A) HSD17B reducing and (B) HSD3B dehydrogenase/isomerase activities in cultured bovine granulosa cells. The cells were cultured for 6 days in serum-free medium with TGFB1. Labeled steroid precursor $\left(\left[{ }^{3} \mathrm{H}\right] \mathrm{E}_{1}\right.$ or $\left.\left[{ }^{3} \mathrm{H}\right] \mathrm{P}_{5}\right)$ was added on day 6 and enzymatic activity assays were conducted as described in Materials and Methods. The $\left[{ }^{3} \mathrm{H}\right] \mathrm{E}_{1}$ precursor was incubated with $10^{-6} \mathrm{M}(1000$-fold excess) unlabeled $E_{1}$ for $1.5 \mathrm{~h}$ and $\left[{ }^{3} \mathrm{H}\right] \mathrm{P}_{5}$ was incubated for $1.5 \mathrm{~h}$ without unlabeled $P_{5}$. Data are means \pm s.E.M. of three separate culture replicates. Compared with the 0 dose control group, TGFB1 treatment did not significantly affect HSD17B reducing activity or HSD3B activity ( $P>0.05, n=3$, one-way ANOVA, with Dunnett's test).

a less mature phenotype, re-establish cell-cell communications, and proliferate in the presence of $\mathrm{FSH}$ (Gutierrez et al. 1997, Marsters et al. 2003). The moderate increase in total cell protein observed in the presence of FSH could indicate that FSH stimulated proliferation or, alternatively, that $\mathrm{FSH}$ prevented apoptosis and increased cell survival. FSH and $E_{2}$ are known to act as survival factors to induce granulosa cell proliferation and prevent apoptosis (Gutierrez et al. 1997, Yang \& Rajamahendran 2000, Jiang et al. 2003, Quirk et al. 2004). In the present study, TGFB1 caused visible differences in the morphology of granulosa cell clumps, which appeared smaller and more spherical than those in FSH-treated controls. TGFB1 at the highest dose also caused a slight decrease in total granulosa cell protein. It is unclear at the present time whether the TGFinduced reduction in steroidogenesis is a result or cause of the change in cell proliferation or survival. But, in the absence of FSH, TGFB1 did not significantly affect total granulosa cell protein. Similarly, TGFB1 alone had no effect on DNA synthesis in cultured bovine granulosa cells (Lerner et al. 1995). Therefore, the effects of TGFB1 on granulosa cells could be due to inhibition of the cellsurviving activity of FSH and/or mediated through a loss of $\mathrm{E}_{2}$-stimulated cell survival (Yang \& Rajamahendran
2000, Quirk et al. 2004). Ongoing experiments in our laboratory will test this hypothesis, by investigating the effects of TGFB1 on proliferation and apoptosis of bovine granulosa cells cultured with or without FSH.

We conclude that TGFB1 plays an inhibitory role in $\mathrm{E}_{2}$ and $\mathrm{P}_{4}$ steroidogenesis in granulosa cells cultured in conditions where $E_{2}$ and $P_{4}$ secretion is being stimulated, and that TGFB1 counteracts the stimulation of mRNA encoding steroidogenic enzymes. As TGFB1 inhibited FSHR mRNA levels and inhibited $\mathrm{FSH}$ induced CYP19A1 and HSD17B1 but not HSD17B7, we propose that the inhibitory effects of TGFB1 on FSHstimulated $\mathrm{E}_{2}$ secretion may be due at least in part to the inhibition of FSHR (Fig. 8). These selective inhibitory effects suggest that TGFB1 may be acting in a physiological manner to limit the amount of $E_{2}$ and $P_{4}$ produced by the granulosa cells without totally shutting down the steroidogenic potential (i.e., HSD17B reducing activity and HSD3B activity are unaffected). By acting in this manner, the physiological role of TGFB1 may be to limit FSH-stimulated growth and differentiation of granulosa cells and play an active role in determining the fate of the developing follicle toward ovulation or atresia.

\section{Materials and Methods}

\section{Experimental design}

As it has not been established whether FSH stimulates all the steroidogenic enzyme genes in granulosa cells, we first determined the effect of $\mathrm{FSH}$ by culturing cells as described below with graded doses of FSH $(0,1$, or $10 \mathrm{ng} / \mathrm{ml})$ for 6 days. Based on these data, the development of gene expression during culture was assessed by culturing cells with $1 \mathrm{ng} / \mathrm{ml} \mathrm{FSH}$ for 2, 4, or 6 days, and the cells were recovered at each time point for the extraction of RNA. Expression of the estrogenic enzyme genes was the highest on day 6; therefore, all subsequent experiments with TGFB1 were performed for 6 days in the presence of $1 \mathrm{ng} / \mathrm{ml} \mathrm{FSH}$.

\section{Cell culture}

Cell culture was performed essentially as described by Gutierrez et al. (1997). Briefly, ovaries were collected at a local abattoir from adult cows irrespective of the stage of the estrous cycle and transported to the laboratory at $37^{\circ} \mathrm{C}$ in PBS containing penicillin $(100 \mathrm{IU} / \mathrm{ml})$, streptomycin $(100 \mu \mathrm{g} / \mathrm{ml})$, and fungizone $(1 \mu \mathrm{g} / \mathrm{ml})$. Follicles of $2-5 \mathrm{~mm}$ in diameter were dissected from the ovaries, and granulosa cells were isolated mechanically by rinsing sections of follicle walls repeatedly through a disposable pipette. The granulosa cell suspension was filtered through a 150 mesh steel sieve (Sigma) to remove oocytes.

The cells were seeded onto 24-well tissue culture plates (Corning Glass Works, Corning, NY, USA) at a density of $10^{6}$ viable cells (tested by Trypan blue exclusion) in $1 \mathrm{ml} \alpha$-MEM with L-glutamine containing sodium bicarbonate $(10 \mathrm{mM})$, 

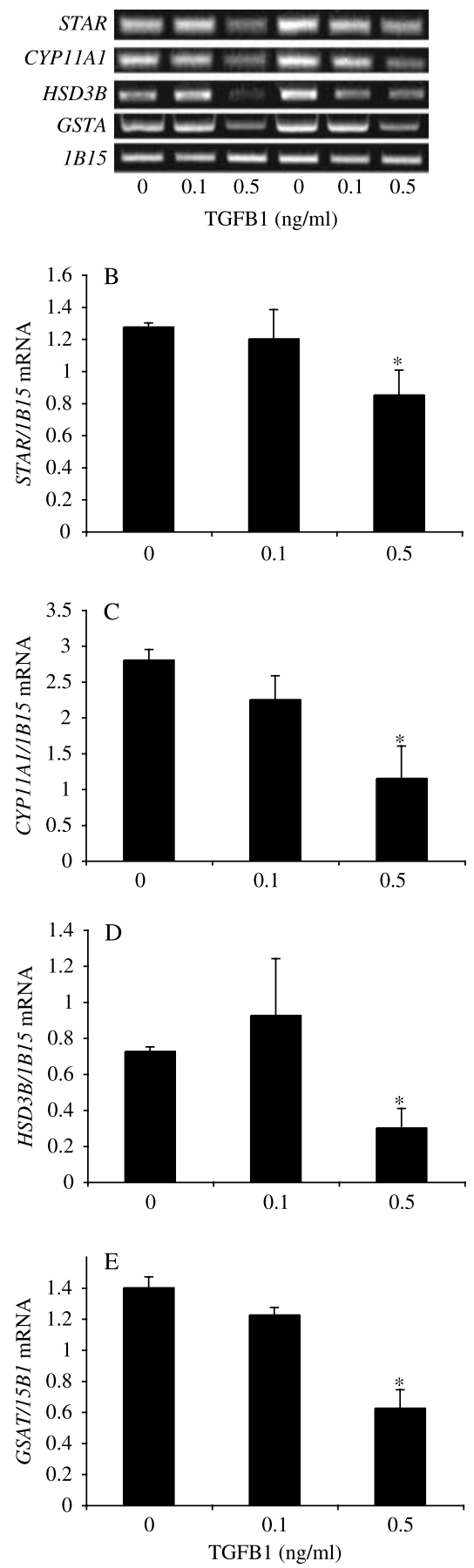
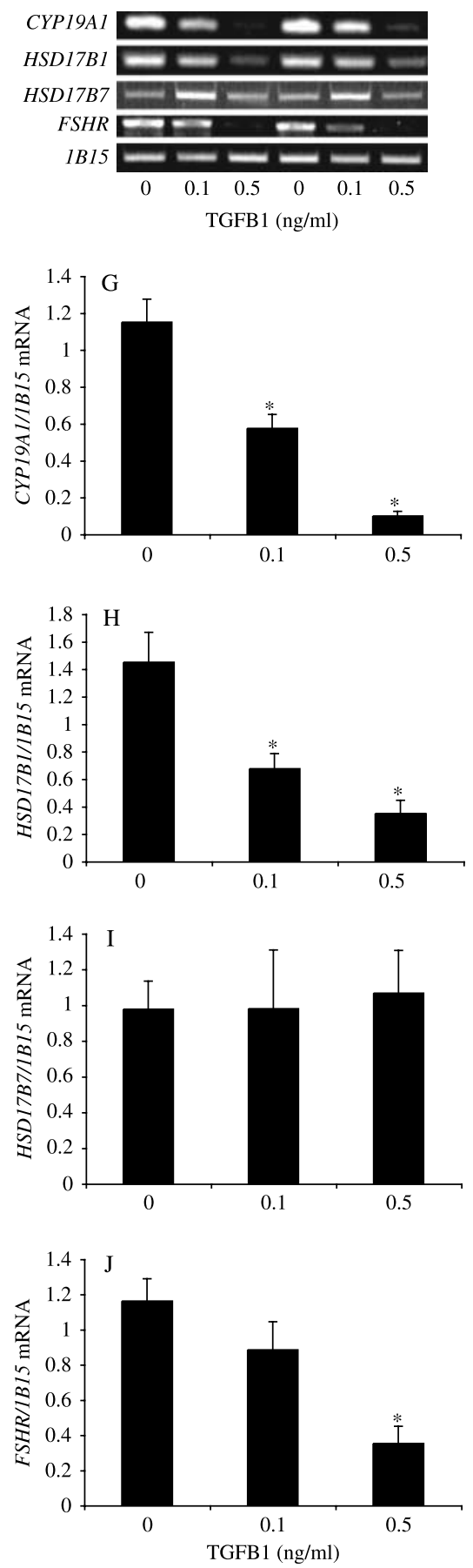

Figure 6 Effect of TGFB1 on mRNA expression of steroidogenic enzymes and $F S H R$ in bovine granulosa cells. The cells were cultured in serumfree medium for 6 days in the presence of $1 \mathrm{ng} / \mathrm{ml}$ FSH with stated doses of TGFB1. (B-E and G-J) Abundance of STAR, CYP11A1, HSD3B, GSTA, CYP19A1, HSD17B1, HSD17B7, and FSHR mRNA was measured by semi-quantitative RT-PCR and normalized to the housekeeping gene $1 B 15$.

Data are means \pm S.E.M. of four separate culture replicates. Asterisk indicates that mRNA content is significantly different from the 0 dose control $(P<0.05$, one-way ANOVA, with Dunnett's test). (A and F) Representative agarose gels from two replicates showing PCR products for each steroidogenic enzyme, FSHR and constitutively expressed housekeeping gene $1 B 15$.
HEPES (20 mM), non-essential amino acid mix (1.1 mM), penicillin $(100 \mathrm{IU} / \mathrm{ml})$ and streptomycin $(100 \mu \mathrm{g} / \mathrm{ml})$, protease-free BSA $(0.1 \%)$, sodium selenite $(4 \mathrm{ng} / \mathrm{ml})$, transferrin $(2.5 \mu \mathrm{g} / \mathrm{ml}), \mathrm{A}_{4}(100 \mathrm{nM}$; all from Sigma), ovine FSH (1 ng/ml; oFSH, AFP-5332B; NIDDKD, Torrance, CA, USA), insulin (10 ng/ml; Invitrogen), and graded doses of recombinant active human TGFB1 (R\&D Systems, Minneapolis, MN, USA) starting on the first day of culture. Cultures were maintained at $37{ }^{\circ} \mathrm{C}$ in $5 \% \mathrm{CO}_{2}$ for 6 days, with $700 \mu \mathrm{l}$ medium being replaced every 2 days.
At the end of culture, the medium was collected and frozen for subsequent steroid assay and granulosa cells were collected for RNA extraction or lysed for total protein measurement. Total cell protein was extracted by the addition of $200 \mu \mathrm{l}$ of $1 \mathrm{M}$ $\mathrm{NaOH}$ to each well for $2 \mathrm{~h}$ at room temperature, followed by neutralization with $200 \mu \mathrm{l}$ of $1 \mathrm{M} \mathrm{HCl}$. Protein concentrations were measured using the Bio-Rad micro-assay (Bio-Rad). All experiments were performed with at least three independent cell cultures, and three to five wells per treatment were pooled for each assay. 
$\mathrm{A}$

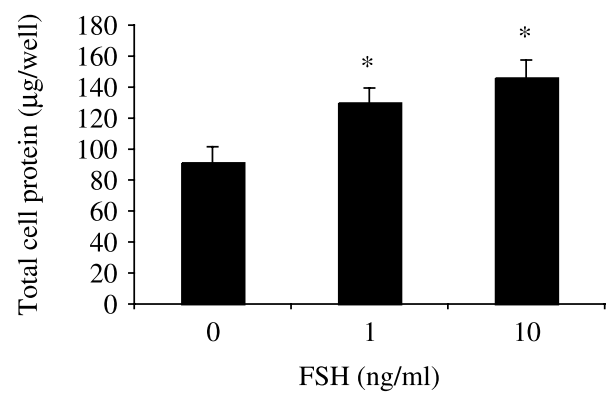

B

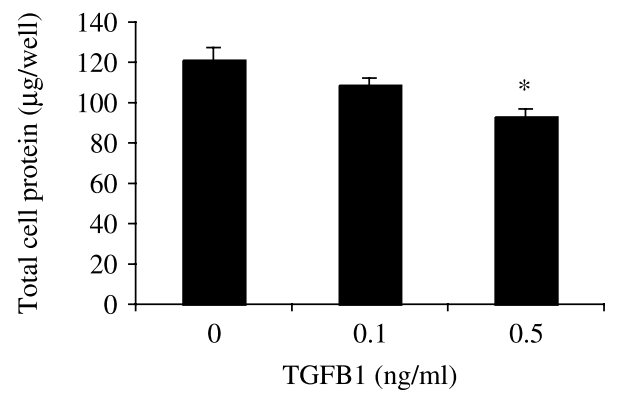

C

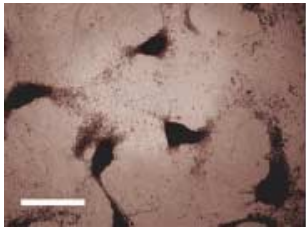

0

D

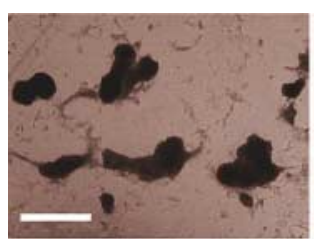

0

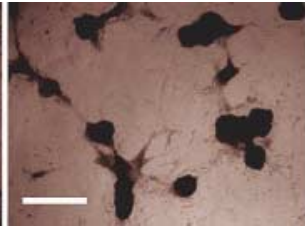

1

$\mathrm{FSH}(\mathrm{ng} / \mathrm{ml})$

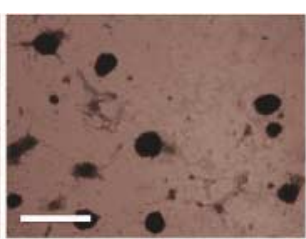

0.1

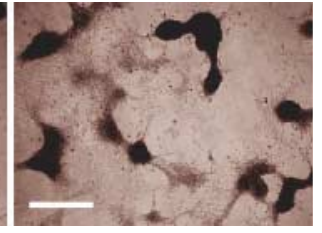

10

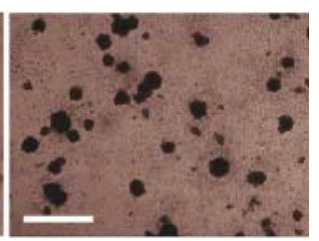

0.5
TGFB1 (ng/ml)

Figure 7 Effect of FSH and TGFB1 on total cell protein and morphology of granulosa cells. The cells were cultured for 6 days in serum-free medium with different doses of (A and C) FSH and (B and D) TGFB1 in the presence of $1 \mathrm{ng} / \mathrm{ml} \mathrm{FSH}$, as described in Materials and Methods. (A and B) Data for total protein content are means \pm S.E.M. of four and six separate culture replicates respectively. Asterisk indicates significant differences compared with the 0 dose control $(P<0.05$, one-way ANOVA, with Dunnett's test). Scale bar, $500 \mu \mathrm{m}$.

\section{Steroid assays}

Culture medium samples were assayed for $E_{2}$ as reported previously (Bélanger et al. 1990), but without C-18 column extraction. Cross-reaction of $\mathrm{A}_{4}$ and $\mathrm{E}_{1}$ with the $\mathrm{E}_{2}$ assay was less than $0.1 \%$ (Bélanger et al. 1980). $\mathrm{P}_{4}$ was measured in duplicate as described (Lafrance \& Goff 1985). Intra- and inter-assay coefficients of variation were less than $15 \%$ for both assays. The sensitivity of the $E_{2}$ and $P_{4}$ assays was 8 and 32 pg per tube respectively. The steroid hormone concentrations were corrected for cell number by normalization to total cell protein per well.

\section{RT-PCR}

Total RNA was extracted using the RNeasy kit (Qiagen), according to the manufacturer's instructions, and treated with DNase (Qiagen). The RT reaction was performed on $1 \mu \mathrm{g}$ total RNA with Omniscript enzyme (Qiagen). Gene expression was measured by semi-quantitative PCR. The primers used were those described previously for cyclophilin (1B15; Bettegowda et al. 2006), CYP11A1 (Vanselow et al. 2004), HSD3B (Vanselow et al. 2004), CYP19A1 (Sahmi et al. 2004), and FSHR (Ndiaye et al. 2005). Sense (5'-TTGTGCGAGAGTCTGGCGATTCT-3') and

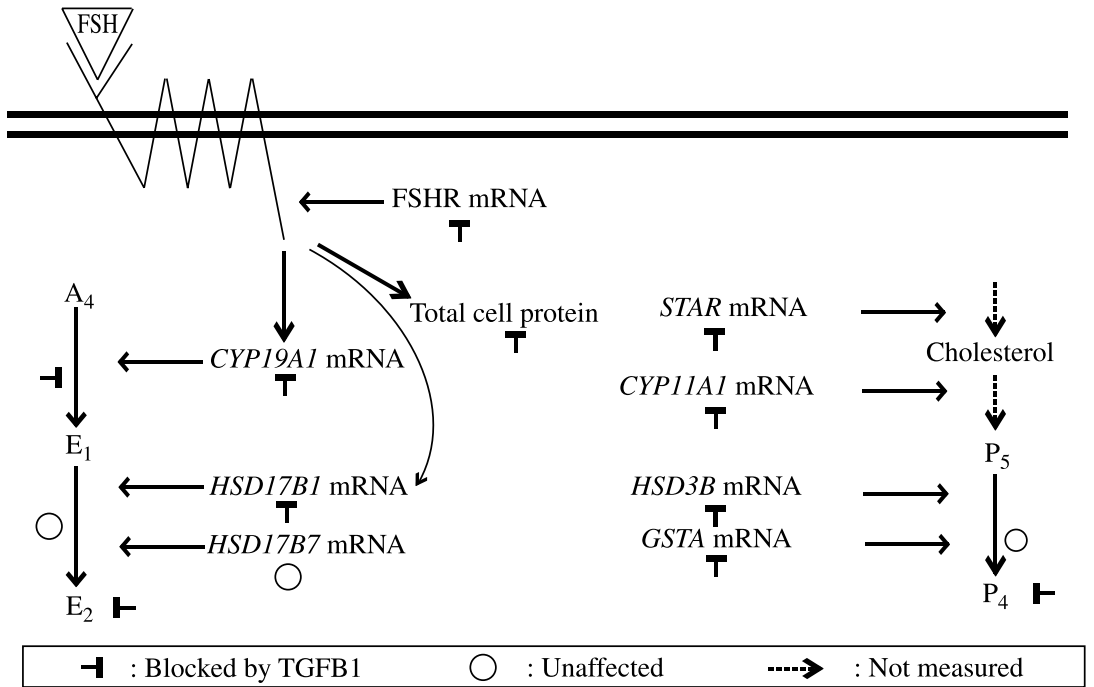

Figure 8 Schematic showing the effect of TGFB1 in the presence of $\mathrm{FSH}(1 \mathrm{ng} / \mathrm{ml})$ on mRNA expression of steroidogenic enzymes and FSHR, total cell protein, and steroidogenic enzyme activity in cultured bovine granulosa cells. The meaning of the signs is shown in the rectangle underneath. 
antisense (5'-AGGAATCGCTCGGTGGTGAAGTA-3 $\left.{ }^{\prime}\right)$ primers for HSD17B1 were designed based on the bovine sequence (NM_001102365) with a product size of $287 \mathrm{bp}$. Sense (5'-CGGTTGCTGGAAGAAGATGATG-3') and antisense (5'-TCACCAGAGGATTGAGAGACTCG-3') primers for HSD17B7 were designed based on the bovine sequence (XM_581467) with a product size of $789 \mathrm{bp}$. Sense (5'-GACACGGTCATCACTCACGAGTT-3') and antisense (5'-ATGCTGAGCAGCCAGGTGAGTT-3') primers for STAR were designed based on the bovine sequence (XM_001250261) with a product size of 248 bp. Sense (5'-GAATGGAGTGCATTCGGTGGCTC- $\left.3^{\prime}\right)$ and antisense (5'-GACTGCTGACTCTGGCTTTTAGG-3') primers for GSTA were designed based on the bovine sequence (BTU49179) with a product size of $528 \mathrm{bp}$. Forward and reverse primers used in the PCRs were located in different exons to avoid amplification of any residual genomic DNA. The PCR products for each gene were sequenced to confirm the identity of the gene. PCR was performed under the following conditions: (1) initial denaturation at $94{ }^{\circ} \mathrm{C}$ for 3 min; (2) amplification cycles of denaturation at $94{ }^{\circ} \mathrm{C}$ for $45 \mathrm{~s}$, annealing for $45 \mathrm{~s}$ at $60{ }^{\circ} \mathrm{C}(\mathrm{CYP} 11 \mathrm{~A} 1, \mathrm{HSD} 3 \mathrm{~B}$, and $F S H R)$ or $64^{\circ} \mathrm{C}$ (HSD17B1, HSD17B7, GSTA), or for $30 \mathrm{~s}$ at $62{ }^{\circ} \mathrm{C}($ STAR, $1 B 15$ and $C Y P 19 A 1$ ); (3) elongation at $72{ }^{\circ} \mathrm{C}$ for $1 \mathrm{~min}$; and (4) final elongation at $72{ }^{\circ} \mathrm{C}$ for $5 \mathrm{~min}$. Optimal cycle number for amplification during the exponential phase was determined for each gene. The reactions were performed for 31 cycles for STAR, 35 cycles for $C Y P 11 A 1,34$ cycles for HSD3B, 25 cycles for GSTA, 29 cycles for $C Y P 19 A 1,36$ cycles for $H S D 17 B 1$ and $H S D 17 B 7,37$ cycles for $F S H R$, and 27 cycles for $1 B 15$. The PCR products were separated on $2 \%$ agarose gels containing $0.001 \%$ ethidium bromide and visualized under u.v. light. Quantification of band intensity was performed with NIH Image J software (http://rsb.info. nih.gov/nih-image/). Target gene mRNA abundance was expressed relative to $1 B 15 \mathrm{mRNA}$ abundance.

\section{Enzyme activity assays}

Short-term incubation of tritiated steroid hormone precursors was conducted at the end of day 6 of culture to measure specific enzyme activities. On day 6, all the medium of each well was removed and replaced with fresh medium without $\mathrm{A}_{4}$ but containing 6-11 nM (corresponding to $1.6 \times 10^{6}$ disintegrations per minute (DPM)/ml medium) of either $\left[{ }^{3} \mathrm{H}\right] \mathrm{E}_{1}$, $\left[{ }^{3} \mathrm{H}\right] \mathrm{A}_{4},\left[{ }^{3} \mathrm{H}\right] \mathrm{T}$, or $\left[{ }^{3} \mathrm{H}\right] \mathrm{P}_{5}$ and $0,0.1$, or $0.5 \mathrm{ng} / \mathrm{ml}$ TGFB1. Cells were incubated for 1.5 or $3 \mathrm{~h}$ at $37^{\circ} \mathrm{C}$. At the end of the incubation, the medium was recovered and frozen at $-20^{\circ} \mathrm{C}$ until analysis of steroid metabolism by thin layer chromatography (TLC) as described previously (Godin et al. 1999). Briefly, steroids were extracted from the medium using diethyl ether and resolved on DC-Alufolien neutral (type E) paper plates (Whatman, Maidstone, Kent, England) in toluene:acetone $(4: 1)$. Each TLC plate contained $\left[{ }^{3} \mathrm{H}\right] \mathrm{E}_{1},\left[{ }^{3} \mathrm{H}\right] \mathrm{E}_{2},\left[{ }^{3} \mathrm{H}\right] \mathrm{A}_{4}$, $\left[{ }^{3} \mathrm{H}\right] \mathrm{T}$, and $\left[{ }^{3} \mathrm{H}\right] \mathrm{P}_{5}$ as standards. A culture medium control was performed by incubating tracer in culture medium without cells, and was used to obtain background radioactivity that was subtracted from product counts. After migration of samples, the TLC plates were exposed to phosphor screens designed for tritium detection, and tritiated steroid metabolites were localized with a Storm 840 Phosphorimager (Molecular Dynamics, Sunnyvale, CA, USA). The rate of production of specific steroid metabolites was quantified by scraping the corresponding sample and background spots from the TLC plate and counting the radioactivity using PCS scintillation fluid (Amersham).

Activity assays were validated by determining the conditions required to maintain excess substrate. In preliminary time-course experiments, $1.6 \times 10^{6}$ DPM of $\left[{ }^{3} \mathrm{H}\right]$ precursor (6-11 nM) were incubated with granulosa cells for 3 and $6 \mathrm{~h}$. The amount of conversion of $\left[{ }^{3} \mathrm{H}\right] \mathrm{A}_{4}$ and $\left[{ }^{3} \mathrm{H}\right] \mathrm{T}$ precursors to $\left[{ }^{3} \mathrm{H}\right] \mathrm{E}_{2}$ was similar with 29 and $58 \%$ conversion after 3 and $6 \mathrm{~h}$ respectively, and thus an incubation time of $3 \mathrm{~h}$ was selected to measure the rate of conversion of $\left[{ }^{3} \mathrm{H}\right] \mathrm{A}_{4}$ and $\left[{ }^{3} \mathrm{H}\right] \mathrm{T}$ to $\left[{ }^{3} \mathrm{H}\right] \mathrm{E}_{2}$. For HSD17B reducing activity, the amount of conversion of $\left[{ }^{3} \mathrm{H}\right] \mathrm{E}_{1}$ precursor to $\left[{ }^{3} \mathrm{H}\right] \mathrm{E}_{2}$ was 92 and $98 \%$ after 3 and $6 \mathrm{~h}$ respectively. Therefore, to obtain experimental conditions of excess precursor, increasing concentrations of unlabeled $\mathrm{E}_{1}\left(10^{-7}, 10^{-6}, 10^{-5} \mathrm{M}\right)$ were added to the $8.8 \mathrm{pmol} / \mathrm{ml}$ of $\left[{ }^{3} \mathrm{H}\right] \mathrm{E}_{1}$, and incubation time was reduced to $1.5 \mathrm{~h}$. This resulted in 6,20 , and $30 \%$ conversion of $\left[{ }^{3} \mathrm{H}\right] \mathrm{E}_{1}$ to $\left[{ }^{3} \mathrm{H}\right] \mathrm{E}_{2}$ respectively, and therefore $10^{-6} \mathrm{M}$ unlabeled $\mathrm{E}_{1}$ was added to all $\left[{ }^{3} \mathrm{H}\right] \mathrm{E}_{1}$ incubations to quantify $\mathrm{HSD} 17 \mathrm{~B}$ reducing activity. For HSD3B activity, the amount of conversion of $\left[{ }^{3} \mathrm{H}\right] \mathrm{P}_{5}$ precursor to $\left[{ }^{3} \mathrm{H}\right] \mathrm{P}_{4}$ was $37,69,79$, and $90 \%$ conversion after $1.5,3,4.5$, and $6 \mathrm{~h}$ respectively, and thus an incubation time of $1.5 \mathrm{~h}$ was selected to measure the rate of conversion of $\left[{ }^{3} \mathrm{H}\right] \mathrm{P}_{5}$ to $\left[{ }^{3} \mathrm{H}\right] \mathrm{P}_{4}$.

\section{Statistical analysis}

Statistical analysis was performed using the JMP software (SAS Institute, Cary, NC, USA). Data are presented as means \pm S.E.M. The data were normally distributed as verified using the Shapiro-Wilk test. One-way ANOVA was used to test the main effect of FSH, time, and TGFB1 on the measured parameters. Differences between treatment dose of FSH or TGFB1 with the 0 dose control or between 4- and 6-day cultures with the 2-day culture group were identified with Dunnett's test.

\section{Declaration of interest}

The authors declare that there is no conflict of interest that could be perceived as prejudicing the impartiality of the research reported.

\section{Funding}

This research was funded by the Natural Sciences and Engineering Research Council (NSERC) of Canada.

\section{Acknowledgements}

We thank Drs B D Murphy and D Boerboom for their constructive criticism of the manuscript, and E S Nicola for technical assistance. 


\section{References}

Attia GR, Dooley CA, Rainey WE \& Carr BR 2000 Transforming growth factor beta inhibits steroidogenic acute regulatory (StAR) protein expression in human ovarian thecal cells. Molecular and Cellular Endocrinology 170 123-129.

Bao B \& Garverick HA 1998 Expression of steroidogenic enzyme and gonadotropin receptor genes in bovine follicles during ovarian follicular waves: a review. Journal of Animal Science 76 1903-1921.

Bao B, Garverick HA, Smith GW, Smith MF, Salfen BE \& Youngquist RS 1997 Changes in messenger ribonucleic acid encoding luteinizing hormone receptor, cytochrome P450-side chain cleavage, and aromatase are associated with recruitment and selection of bovine ovarian follicles. Biology of Reproduction 56 1158-1168.

Bao B, Calder MD, Xie S, Smith MF, Salfen BE, Youngquist RS \& Garverick HA 1998 Expression of steroidogenic acute regulatory protein messenger ribonucleic acid is limited to theca of healthy bovine follicles collected during recruitment, selection, and dominance of follicles of the first follicular wave. Biology of Reproduction 59 953-959.

Bélanger A, Caron S \& Picard V 1980 Simultaneous radioimmunoassay of progestins, androgens and estrogens in rat testis. Journal of Steroid Biochemistry 13 185-190.

Bélanger A, Couture J, Caron S \& Roy R 1990 Determination of nonconjugated and conjugated steroid levels in plasma and prostate after separation on C-18 columns. Annals of the New York Academy of Sciences 595 251-259.

Bettegowda A, Patel OV, Ireland JJ \& Smith GW 2006 Quantitative analysis of messenger RNA abundance for ribosomal protein L-15, cyclophilin-A, phosphoglycerokinase, beta-glucuronidase, glyceraldehyde 3-phosphate dehydrogenase, beta-actin, and histone $\mathrm{H} 2 \mathrm{~A}$ during bovine oocyte maturation and early embryogenesis in vitro. Molecular Reproduction and Development 73 267-278.

Chang WY, Uzumcu M \& Lin YC 1996 Effects of transforming growth factor$\beta 1$ and activin-A on in vitro porcine granulosa cell steroidogenesis. Theriogenology 45 1463-1472.

Cherradi N, Chambaz EM \& Defaye G 1995 Type beta 1 transforming growth factor is an inhibitor of 3 beta-hydroxysteroid dehydrogenase isomerase in mouse adrenal tumor cell line Y1. Endocrine Research $\mathbf{2 1}$ $61-66$.

Drummond AE 2006 The role of steroids in follicular growth. Reproductive Biology and Endocrinology 416.

Ford JJ \& Howard HJ 1997 Activin inhibition of estradiol and progesterone production in porcine granulosa cells. Journal of Animal Science $\mathbf{7 5}$ 761-766.

Fortune JE 1986 Bovine theca and granulosa cells interact to promote androgen production. Biology of Reproduction 35 292-299.

Fortune JE, Rivera GM, Evans AC \& Turzillo AM 2001 Differentiation of dominant versus subordinate follicles in cattle. Biology of Reproduction 65 648-654.

Gautier C, Levacher C, Saez JM \& Habert R 1997 Transforming growth factor beta1 inhibits steroidogenesis in dispersed fetal testicular cells in culture. Molecular and Cellular Endocrinology 131 21-30.

Godin C, Provost PR, Poirier D, Blomquist CH \& Tremblay Y 1999 Separation by thin-layer chromatography of the most common androgen-derived C19 steroids formed by mammalian cells. Steroids 64 767-769.

Gutierrez CG, Campbell BK \& Webb R 1997 Development of a long-term bovine granulosa cell culture system: induction and maintenance of estradiol production, response to follicle-stimulating hormone, and morphological characteristics. Biology of Reproduction 56 608-616.

Herrmann M, Scholmerich J \& Straub RH 2002 Influence of cytokines and growth factors on distinct steroidogenic enzymes in vitro: a short tabular data collection. Annals of the New York Academy of Sciences 966 166-186.

Hillier SG, Whitelaw PF \& Smyth CD 1994 Follicular oestrogen synthesis: the 'two-cell, two-gonadotrophin' model revisited. Molecular and Cellular Endocrinology 100 51-54.

Ireland JJ \& Roche JF 1982 Development of antral follicles in cattle after prostaglandin-induced luteolysis: changes in serum hormones, steroids in follicular fluid, and gonadotropin receptors. Endocrinology 111 2077-2086.
Ireland JJ, Mihm M, Austin E, Diskin MG \& Roche JF 2000 Historical perspective of turnover of dominant follicles during the bovine estrous cycle: key concepts, studies, advancements, and terms. Journal of Dairy Science 83 1648-1658.

Irving-Rodgers HF, Krupa M \& Rodgers RJ 2003 Cholesterol side-chain cleavage cytochrome P450 and 3beta-hydroxysteroid dehydrogenase expression and the concentrations of steroid hormones in the follicular fluids of different phenotypes of healthy and atretic bovine ovarian follicles. Biology of Reproduction 69 2022-2028.

Jiang JY, Cheung CK, Wang Y \& Tsang BK 2003 Regulation of cell death and cell survival gene expression during ovarian follicular development and atresia. Frontiers of Bioscience $\mathbf{8} \mathrm{d} 222-\mathrm{d} 237$.

Juengel JL \& McNatty KP 2005 The role of proteins of the transforming growth factor-beta superfamily in the intraovarian regulation of follicular development. Human Reproduction Update 11 143-160.

Juengel JL, Bibby AH, Reader KL, Lun S, Quirke LD, Haydon LJ \& McNatty KP 2004 The role of transforming growth factor-beta (TGF-beta) during ovarian follicular development in sheep. Reproductive Biology and Endocrinology 2 78-88.

Knight PG \& Glister C 2006 TGF- $\beta$ superfamily members and ovarian follicle development. Reproduction 132 191-206.

Kolibianakis EM, Papanikolaou EG, Fatemi HM \& Devroey P 2005 Estrogen and folliculogenesis: is one necessary for the other? Current Opinion in Obstetrics and Gynecology 17 249-253.

Krazeisen A, Breitling R, Imai K, Fritz S, Moller G \& Adamski J 1999 Determination of cDNA, gene structure and chromosomal localization of the novel human 17beta-hydroxysteroid dehydrogenase type $7(1)$. FEBS Letters $460373-379$.

Krusche CA, Moller G, Beier HM \& Adamski J 2001 Expression and regulation of 17beta-hydroxysteroid dehydrogenase 7 in the rabbit. Molecular and Cellular Endocrinology 171 169-177.

Lafrance M \& Goff AK 1985 Effect of pregnancy on oxytocin-induced release of prostaglandin F2 alpha in heifers. Biology of Reproduction 33 1113-1119.

Lerner AA, Salamone DF, Chiappe ME \& Baranao JL 1995 Comparative studies between freshly isolated and spontaneously immortalized bovine granulosa cells: protein secretion, steroid metabolism, and responsiveness to growth factors. Journal of Cellular Physiology 164 395-403.

Luo S, Yu H, Wu D \& Peng C 2002 Transforming growth factor-beta1 inhibits steroidogenesis in human trophoblast cells. Molecular Human Reproduction 8 318-325.

Lussier JG, Matton P \& Dufour JJ 1987 Growth rates of follicles in the ovary of the cow. Journal of Reproduction and Fertility 81 301-307.

Marsters P, Kendall NR \& Campbell BK 2003 Temporal relationships between $\mathrm{FSH}$ receptor, type 1 insulin-like growth factor receptor, and aromatase expression during $\mathrm{FSH}$-induced differentiation of bovine granulosa cells maintained in serum-free culture. Molecular and Cellular Endocrinology 203 117-127.

Mindnich R, Moller G \& Adamski J 2004 The role of 17 beta-hydroxysteroid dehydrogenases. Molecular and Cellular Endocrinology 218 7-20.

Naaman-Reperant E, Hales DB \& Durand P 1996 Effect of transforming growth factor beta-1 on the cholesterol side-chain cleavage system in the adrenal gland of sheep fetuses and newborns. Endocrinology 137 886-892.

Ndiaye K, Fayad T, Silversides DW, Sirois J \& Lussier JG 2005 Identification of downregulated messenger RNAs in bovine granulosa cells of dominant follicles following stimulation with human chorionic gonadotropin. Biology of Reproduction 73 324-333.

Nilsson EE, Doraiswamy V \& Skinner MK 2003 Transforming growth factorbeta isoform expression during bovine ovarian antral follicle development. Molecular Reproduction and Development 66 237-246.

Nokelainen P, Peltoketo H, Vihko R \& Vihko P 1998 Expression cloning of a novel estrogenic mouse 17 beta-hydroxysteroid dehydrogenase/17ketosteroid reductase (m17HSD7), previously described as a prolactin receptor-associated protein (PRAP) in rat. Molecular Endocrinology 12 1048-1059.

Ouellette Y, Price CA \& Carriere PD 2005 Follicular fluid concentration of transforming growth factor-beta1 is negatively correlated with estradiol and follicle size at the early stage of development of the first-wave cohort of bovine ovarian follicles. Domestic Animal Endocrinology 29 623-633.

Price CA, Carriere PD, Gosselin N, Kohram H \& Guilbault LA 1999 Effects of superovulation on endogenous LH secretion in cattle, and consequences for embryo production. Theriogenology 51 37-46. 
Quirk SM, Cowan RG, Harman RM, Hu CL \& Porter DA 2004 Ovarian follicular growth and atresia: the relationship between cell proliferation and survival. Journal of Animal Science 82 E40-E52.

Rabahi F, Brule S, Sirois J, Beckers JF, Silversides DW \& Lussier JG 1999 High expression of bovine alpha glutathione $S$-transferase (GSTA1, GSTA2 subunits is mainly associated with steroidogenically active cells and regulated by gonadotropins in bovine ovarian follicles. Endocrinology 140 3507-3517.

Raffalli-Mathieu F, Persson D \& Mannervik B 2007 Differences between bovine and human steroid double-bond isomerase activities of Alphaclass glutathione transferases selectively expressed in steroidogenic tissues. Biochimica et Biophysica Acta 1770 130-136.

Rainey WE, Naville D \& Mason JI 1991 Regulation of 3 beta-hydroxysteroid dehydrogenase in adrenocortical cells: effects of angiotensin-II and transforming growth factor beta. Endocrine Research 17 281-296.

Rainey WE, Price TM, Means GD \& Carr BR 1992 Effect of type 1 transforming growth factor-beta on the level of aromatase cytochrome P-450 in human fetal hepatocytes. Journal of Endocrinology 133 311-320.

Risk M, Shehu A, Mao J, Stocco CO, Goldsmith LT, Bowen-Shauver JM \& Gibori G 2005 Cloning and characterization of a 5' regulatory region of the prolactin receptor-associated protein $/ 17 \beta$ hydroxysteroid dehydrogenase 7 gene. Endocrinology 146 2807-2816.

Sahmi M, Nicola ES, Silva JM \& Price CA 2004 Expression of $17 \beta$ - and $3 \beta$-hydroxysteroid dehydrogenases and steroidogenic acute regulatory protein in non-luteinizing bovine granulosa cells in vitro. Molecular and Cellular Endocrinology 223 43-54.

Silva MJ \& Price CA 2000 Effect of follicle-stimulating hormone on steroid secretion and messenger ribonucleic acids encoding cytochromes P450 aromatase and cholesterol side-chain cleavage in bovine granulosa cells in vitro. Biology of Reproduction 62 186-191.

Simpson ER, Merrill JC, Hollub AJ, Graham-Lorence S \& Mendelson CR 1989 Regulation of estrogen biosynthesis by human adipose cells. Endocrine Reviews 10 136-148.
Soumano K \& Price CA 1997 Ovarian follicular steroidogenic acute regulatory protein, low-density lipoprotein receptor, and cytochrome P450 side-chain cleavage messenger ribonucleic acids in cattle undergoing superovulation. Biology of Reproduction 56 516-522.

Vanselow J, Furbass R, Rehbock F, Klautschek G \& Schwerin M 2004 Cattle and sheep use different promoters to direct the expression of the aromatase cytochrome P450 encoding gene, Cyp19, during pregnancy. Domestic Animal Endocrinology 27 99-114.

Wandji SA \& Fortune JE 1996 FSH and growth factors affect the growth and endocine function in vitro of granulosa cells of bovine preantral follicles. Theriogenology 45 817-832.

Xu Z, Garverick HA, Smith GW, Smith MF, Hamilton SA \& Youngquist RS 1995 Expression of messenger ribonucleic acid encoding cytochrome P450 side-chain cleavage, cytochrome p450 17 alpha-hydroxylase, and cytochrome P450 aromatase in bovine follicles during the first follicular wave. Endocrinology 136 981-989.

Yang MY \& Rajamahendran R 2000 Morphological and biochemical identification of apoptosis in small, medium, and large bovine follicles and the effects of follicle-stimulating hormone and insulin-like growth factor-I on spontaneous apoptosis in cultured bovine granulosa cells. Biology of Reproduction 62 1209-1217.

Zachow RJ, Weitsman SR \& Magoffin DA 1999 Leptin impairs the synergistic stimulation by transforming growth factor-beta of folliclestimulating hormone-dependent aromatase activity and messenger ribonucleic acid expression in rat ovarian granulosa cells. Biology of Reproduction 61 1104-1109.

Received 9 July 2007

First decision 7 September 2007

Revised manuscript received 2 July 2008

Accepted 17 July 2008 